\title{
Trace-element systematics of sulphides in the Kevitsa Ni-Cu-PGE deposit, northern Finland
}

\author{
E. Capuano ${ }^{1}$, S.H. Yang ${ }^{1 *}$, K. Luolavirta ${ }^{1}$ and H. O’Brien ${ }^{2}$ \\ ${ }^{1}$ Oulu Mining School, University of Oulu \\ ${ }^{2}$ Geological Survey of Finland, Espoo \\ *Corresponding author e-mail: shenghong.yang@oulu.fi
}

\begin{abstract}
Summary Kevitsa has been one of Europe's most important nickel mines. To enhance our understanding of the ore-forming and post-magmatic processes that occurred in the Kevitsa intrusion, we determined PGE concentrations of the main sulphide phases from the main ore types using laser ablation-inductively coupled plasma mass spectrometry (LA-ICP-MS). Although the origin of the Ni-PGE ore remains ambiguous, it is clear that the formation was dominated by magmatic processes and hydrothermal redistribution of metal played an insignificant role.
\end{abstract}

\section{Introduction and background to current research}

The Kevitsa mafic-ultramafic intrusion is located in the Central Lapland Greenstone Belt, in Finnish Lapland, and hosts a large Ni-Cu-(PGE) sulphide deposit (Fig. 1a). The Kevitsa intrusion emplaced into the Savukoski volcanic sedimentary formation, and is composed of a lower ultramafic unit and an upper gabbroic unit (Fig. 1b). The Ni-Cu-(PGE) sulfide deposit occur in the middle of the ultramafic part (Fig. 1c). Kevitsa mine has been in operation since 2012, and it is one of Europe's most recent nickel mines and has an annual output in the range of 9000-10,000 t of nickel, 17,000-19,000 of copper and 22,000-24,000 oz each of platinum and palladium (Santaguida et al., 2015). Generally, multiple stage magmatic processes and intensive interaction between magma and sedimentary rocks are proposed to account for the complicated mineralization in Kevitsa (Yang et al., 2013; Luolavirta et al., 2018a, b). This work is a master thesis project aims to provide further constraints on the ore-formation processes at Kevitsa by studying the trace-element characteristics of the base metal sulfides at Kevitsa.

\section{Research questions at hand}

Though as by product, the Kevitsa deposit is an important producer of platinum group metals. However, the detailed mechanism for PGE enrichment is under debate. Base on texture of platinum group minerals, it is suggested that hydrothermal fluid process has played an important role in redistribution of PGEs, forming unusual PGE enrichment in some part of the intrusion (Gervilla and Kojonen, 2002). However, based on the good correlation between different PGEs and detailed textural study, it is suggested that the fluid redistribution of metals is not significant, except $\mathrm{Cu}$ and $\mathrm{Au}$ (Le Vaillant et al., 2016). In this study, in-situ trace element study of base metal sulfide has been conducted to further constrain the metal enrichment processes.

There are two main ore types that make up the economic resources, named normal ore and Ni-PGE ore (Mutanen, 1997). The normal ore is more continuous and comprises $90 \%$ of the volume, and Ni-PGE ore occurs as discontinuous lense like bodies. The normal ore has average $\mathrm{Ni}$ and $\mathrm{Cu}$ grades of 0.3 and $0.42 \mathrm{wt} . \%$ and the main sulfide minerals are pentlandite, chalcopyrite and pyrrhotite (Fig. 2a). The Ni-PGE ore consists predominantly of pentlandite, pyrite and millerite (Fig. 2b, c), with higher and more variable $\mathrm{Ni}$ grades, lower $\mathrm{Cu}$ grades $(\mathrm{Ni} / \mathrm{Cu} 1.5-15)$ and high Ni tenors (generally $>10 \%$ ). The Ni-PGE ore also has a high PGE content ranging from $>1 \mathrm{ppm}$, much higher than that of the normal ore $(0.5$ to $1 \mathrm{ppm}$ of 
combined $\mathrm{Pt}, \mathrm{Pd}$ and $\mathrm{Au}$ ). In addition, there is an uneconomic ore type, called false ore, which consists of pyrrhotite, with rare chalcopyrite and pentlandite, and generally has low Ni content of less than $<0.1$ wt. $\%$.

To examine the ore-forming processes that occurred during the cooling and crystallisation of the Kevitsa magma chamber, and post-magmatic modification, in this study, trace-elements of the main sulphide minerals were analysed using laser ablation-inductively coupled plasma mass spectrometry (LA-ICP-MS) (Fig. 3). Although Pd is found in all of the sulphide phases, pentlandite is the richest, with Pd contents ranging from $0.3 \mathrm{ppm}$ in false ore to tens of ppm in the Ni-PGE ore. Pentlandite in the normal ore has Pd contents falling between the false and Ni-PGE ore type (Fig. 4a, b). Barnes et al. (2011) suggest millerite could form in a high Ni sulfide melt, though it is rare. More commonly, millerite occur as secondary alteration products (e.g., Vaara, Konnunaho et al., 2013). In Kevitsa, millerite and pyrite contain certain amount of both IPGEs and PPGEs, together with the well preserved primary texture, we confirm that these two phases are formed in magmatic stage (Fig. 4b). Pyrrhotite contains relatively high IPGEs, but lower PPGEs, and chalcopyrite contain the lowest amount PGEs, which is similar to the study on other deposits (Godel., et al., 2007). Pt contents are low in all the base metal sulphides, with the majority of analyses falling below the detection limit, indicating Pt bearing platinum group minerals are the main host.
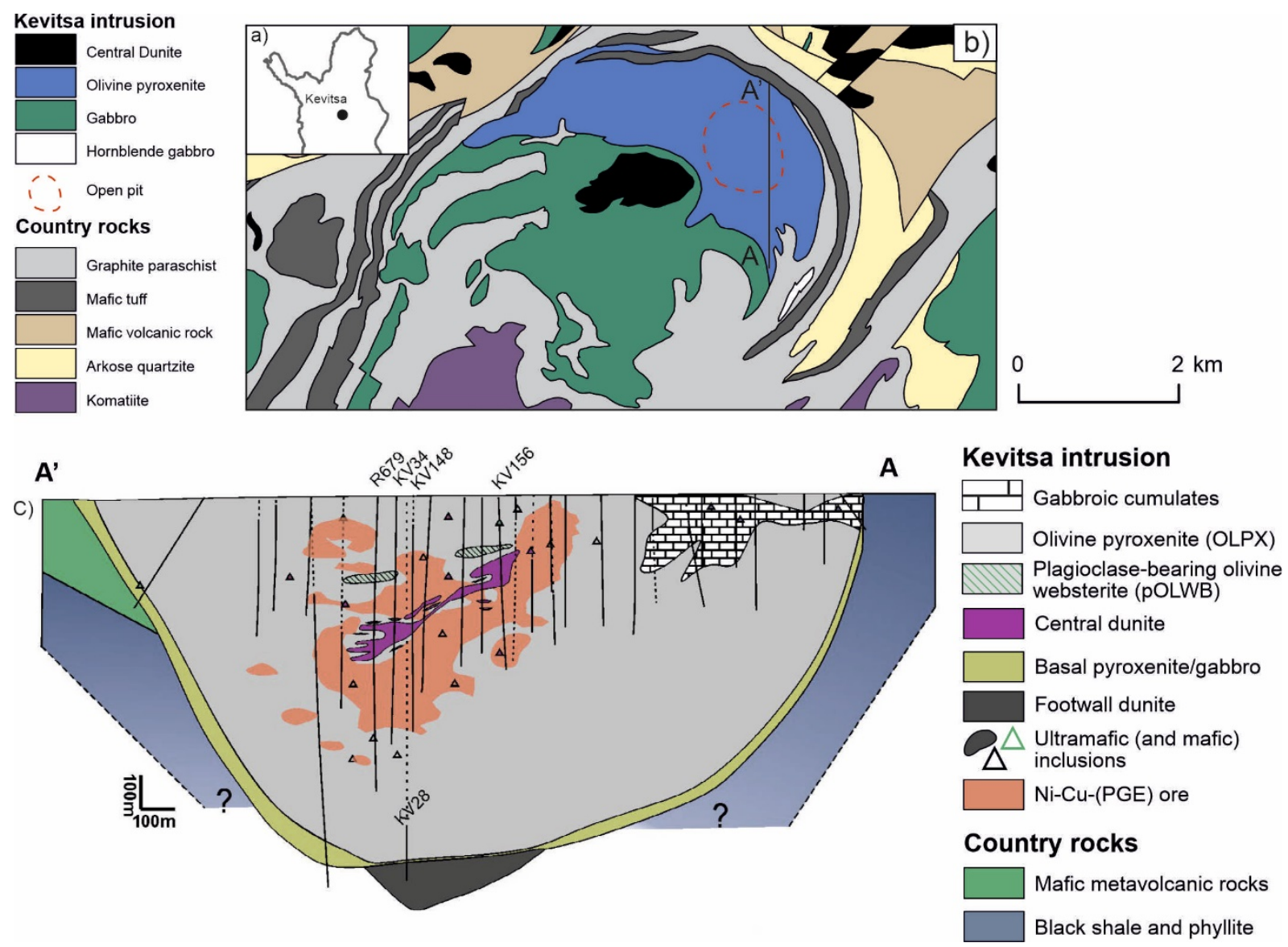

Figure 4. Geological map of the Kevitsa intrusion.

Generally, samples with higher PGE tenors show high PGE content in base metal sulfides (Fig. 4c). This indicates a magmatic origin for high metal tenors in the Ni-PGE ore, 
with a negligible effect of post-magmatic fluid enrichment. On the other hand, the false ores show very low metal contents for all chalcophile metals, indicating crystallization from a sulfide saturated magma, and an earlier stage of sulfide saturation may have occurred at depth (Fig. $4 c)$.
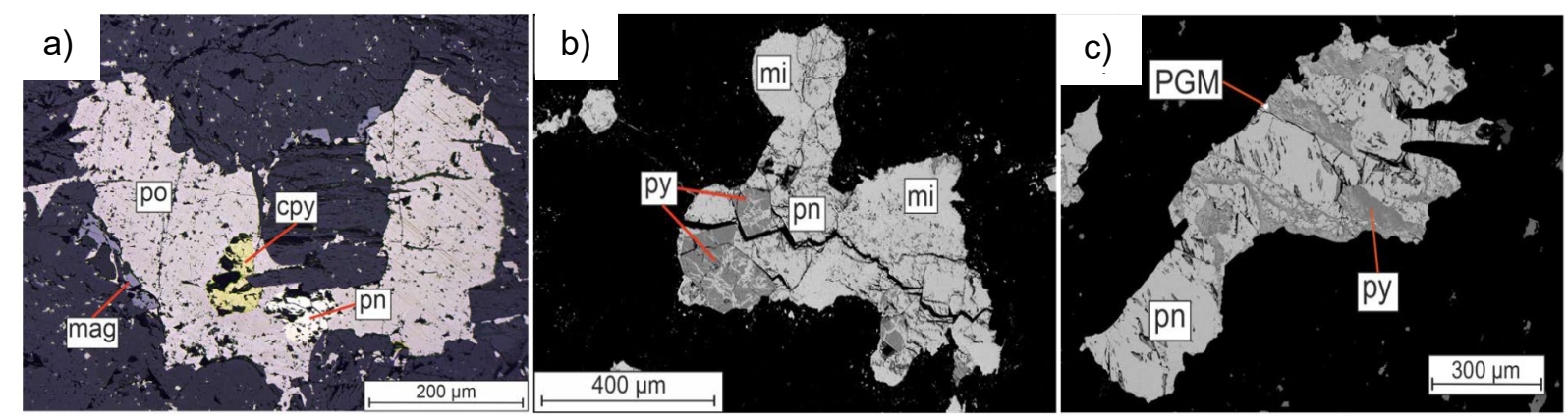

Figure 5. Base metal sulfide mineral texture of different ore types in Kevitsa. a) pyrrhotite (Po), pentlandite (Pn), and chalcopyrite (Cpy); b) Ni-PGE ores with well preserved association of millerite (Mi), Pn, and pyrite (Py); c) another Ni-PGE ore sample showing intergrowth of Pn and Py.

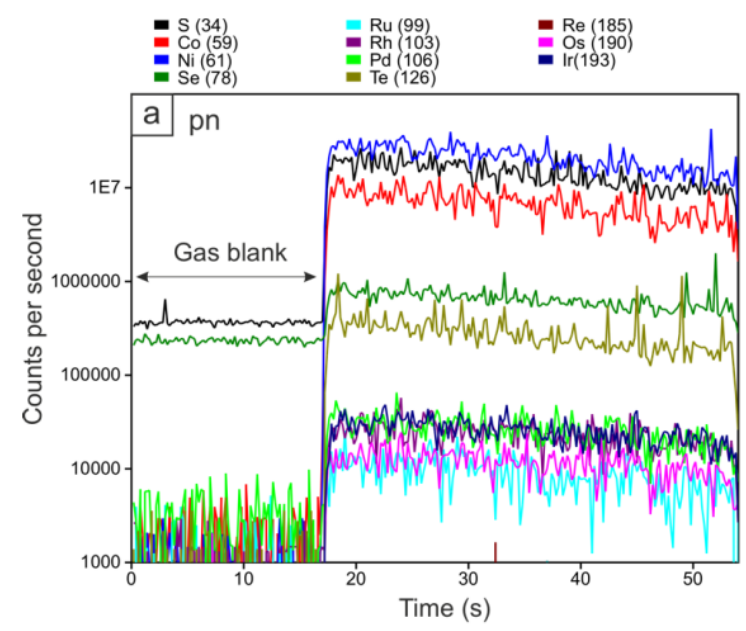

Figure 3. TRA spectra (counts per second vs. time in seconds) from laser ablation analyses of a pentlandite.
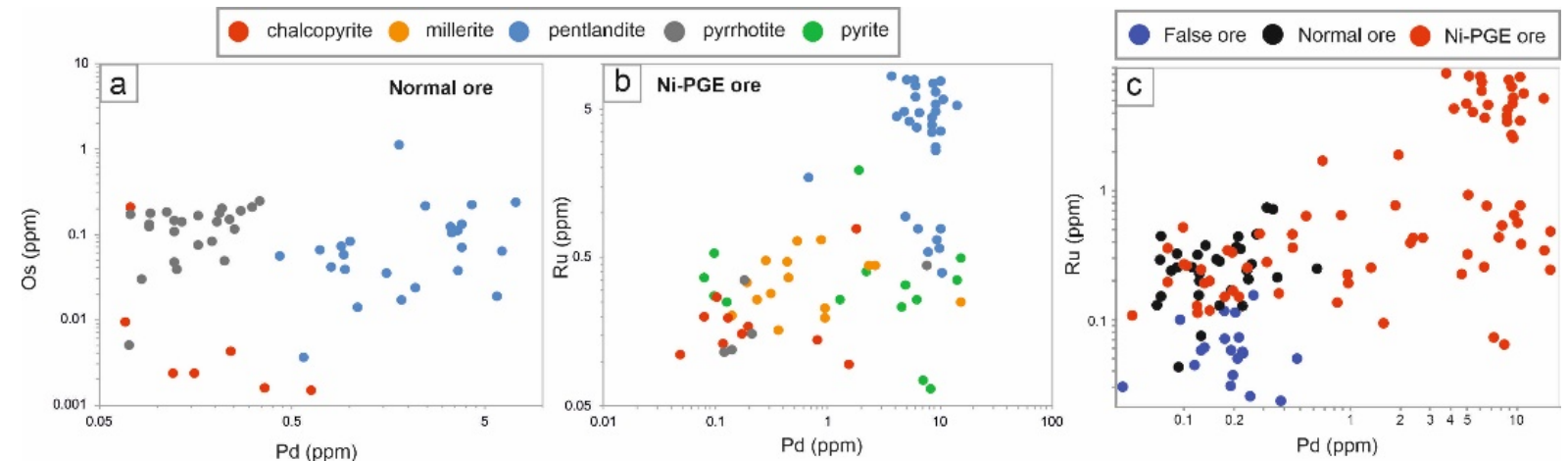

Figure 4. PGE content of base metal sulfide: a) Os and Pd content in different sulfide minerals (pyrrhotite, pentlandite and chalcopyrite) in normal ore; b) $\mathrm{Ru}$ and $\mathrm{Pd}$ content in different sulfide minerals in Ni-PGE ore; c) Ru and Pd in pentlandite in different types of ores. 


\section{Future research}

We have done some preliminary mass balance study on the PGE budget in base metal sulfide compared with platinum group minerals. More detailed work could be conducted in the future.

In addition, the in-situ trace element study of sulfide minerals, and also arsenides, sulpharsenides could potentially be applied to other layered intrusions in Finland, to constrain the metal enrichment mechanisms.

\section{Acknowledgements}

This project is funded by Renlund foundation.

\section{References:}

Godel B, Barnes SJ, Maier WD (2007) Platinum-group elements in sulphide minerals, platinum-group minerals, and whole-rocks of the Merensky Reef (Bushveld Complex, South Africa): implications for the formation of the reef. J Petrol, 48:1569-604.

Barnes SJ, Godel BM, Locmelis M, Fiorentini ML, Ryan CG (2011) Extremely Ni-rich Fe-Ni sulfide assemblages in dunite at Betheno, Western Australia: results from synchrotron X-ray fluorescence mapping. Aust J Earth Sci 58:691-709

Gervilla F, Kojonen K (2002) The platinum-group minerals in the upper section of the Keivitsansarvi Ni-Cu-PGE deposit, Northern Finland. Can Mineral 40:377-394.

Konnunaho JP, Hanski EJ, Bekker A, Halkoaho TA, Hiebert RS, Wing BA (2013) The Archean komatiite-hosted, PGE-bearing Ni-Cu sulfide deposit at Vaara, eastern Finland: evidence for assimilation of external sulfur and post-depositional desulfurization. Mineral Depos. 48:967-89.

Mutanen T (1997) Geology and ore petrology of the Akanvaara and Koitelainen mafic layered intrusions and the Keivitsa-Satovaara layered complex, northern Finland. Geol Surv Finl Bull 395: pp 233.

Le Vaillant M, Barnes SJ, Fiorentini ML, Santaguida F, Törmänen T (2016) Effects of hydrous alteration on the distribution of base metals and platinum group elements within the Kevitsa magmatic nickel sulphide deposit. Ore Geol Rev, 72:128-48.

Luolavirta, K., Hanski, E., Maier, W., Lahaye, Y., O’Brien, H. and Santaguida, F., 2018a. In situ strontium and sulfur isotope investigation of the Ni-Cu-(PGE) sulfide ore-bearing Kevitsa intrusion, northern Finland. Mineral Depos, 53: 1019-1038.

Luolavirta K, Hanski E, Maier W, Santaguida F (2018b) Whole-rock and mineral compositional constraints on the magmatic evolution of the Ni-Cu-(PGE) ore-bearing Kevitsa intrusion, northern Finland. Lithos 296299:37-53

Santaguida F, Luolavirta K, Lappalainen M, Ylinen J, Voipio T, Jones S (2015) The Kevitsa Ni-Cu-PGE Deposit in the Central Lapland Greenstone Belt in Finland. In: WD Maier, H O'Brien, R Lahtinen, (eds) Mineral Deposits of Finland. Elsevier, Amsterdam pp. 195-210.

Yang S, Maier WD, Hanski EJ, Lappalainen M, Santaguida F, Määttä S (2013) Origin of ultra-nickeliferous olivine in the Kevitsa Ni-Cu-PGE-mineralized intrusion, northern Finland. Contrib Mineral Petrol 166: 81-95. 